\title{
Long QT Syndrome - A case report
}

\author{
Erwan Martanto, Surya Dharma, Syarif Subiyakto, Muhammad Munawar
}

\begin{abstract}
Abstrak
Sindroma pemanjangan QT (Long QT syndrome) diakibatkan oleh defek genetik, merupakan kasus jarang, sering disertai dengan takikardia ventricular polimorfik ('torsade de pointes'- TdP) dan dapat menyebabkan kematian mendadak. Dilaporkan kasus seorang wanita 25 tahun dengan riwayat berdebar, sakit kepala dan pingsan yang berulang sejak usia 16 tahun. Rekaman elektrokardiogram menunjukkan adanya ekstra-sistol ventrikular bigemini, interval QT terkoreksi memanjang dan gelombang T abnormal. Pascapersalinan pertama penderita didiagnosis sebagai kardiomiopati peripartal. Juli 2002 dirawat karena masalah pingsan dan kejang disertai TdP dan fibrilasi ventrikular. Keadaan ini dapat diatasi dengan beberapa kali pemberian renjatan aliran arus searah (DC), pemasangan pacu jantung sementara dengan laju jantung yang relatif tinggi. Penderita dipulangkan dengan penyekat beta dan pemasangan pacu-jantung tetap kamar ganda. Selama 4 bulan pemantauan, penderita tanpa keluhan. (Med J Indones 2003; 12: 109-13)
\end{abstract}

\begin{abstract}
Long QT syndrome (LQTS) is an uncommon disease due to genetic defect and responsible for polymorphic VT (torsade-de pointes$T d P)$ and sudden cardiac death. A case of 25 year-old woman with palpitation, severe headache and recurrent syncopal episode since 16 year-old is reported. The ECG showed bigeminy ventricular premaure contraction (VPC), prolonged QTc interval and abnormal $T$ wave. Peripartal cardiomyopathy was diagnosed recently after the first delivery. In July 2002, she was hospitalized due to recurrent syncope, seizure proceeded by TdP and VF. On admission she need several times DC shock and temporary pacemaker with relatively high rate. Beta-blocker and implantation of dual chamber permanent pacemaker finally could control the malignant arrhythmias. During follow-up for 4 months, she was doing well and no syncopal episode occurred. (Med J Indones 2003; 12: 109-13)
\end{abstract}

Keywords: LQTS, arrhythmia, pacemaker, beta-blocker

Long-QT Syndrome (LQTS) is a cardiovascular disorder characterized by prolongation of the QT interval on ECG and presence of syncope, seizures, and sudden death. ${ }^{1,2}$ Six genes have been implicated in Romano-Ward syndrome, the autosomal dominant form of LQTS. Mutations in KVLQT1 and KCNE1 also cause the Jervell and Lange-Nielsen syndrome, a form of LQTS associated with deafness, a phenotypic abnormality inherited in an autosomal recessive fashion. ${ }^{3}$ Unfortunately the incidence rate is unknown, but estimated to be about 1:10.000 to $1: 15.000$ and female gender is prevalent. ${ }^{4}$

National Cardiovascular Centre Harapan Kita, Department of Cardiology, Faculty of Medicine University of Indonesia, Jakarta, Indonesia emotional stress and proceeded by severe headache. She has history of normal delivery, but then was diagnosed as having peripartal cardiomyopathy since the first delivery. There was recurrent syncopal episode during her pregnancies. On 1993, she had a history of taking sulfas quinidine $100 \mathrm{mgs}$ t.i.d for 6 months and her last medication was only vitamins. Congenital deafness and epilepsy was recognized in her second and third brothers.

On early July 2002 she was admitted to our hospital because of recurrent syncope. On admission, she was fully alert, with mild hypotension $(90 / 60 \mathrm{mmHg}$ ) and tachycardia.

Physical examination revealed no abnormality detected. Laboratory findings are within normal limit. The chest x-ray showed her heart was markedly enlarged but no sign of increased pulmonary vein 
pressure. Surface ECG revealed sinus rhythm, prolonged corrected QT interval (0.66 second) and wide-displayed inverted $\mathrm{T}$ wave at the lead I, II, III, aVF, V2 to V6 (Figure 1). Two dimension echocardiography revealed a dilatation of all cardiac chambers, global hypokinetic and poor left ventricular function (left ventricular ejection fraction was 27\%). There was documented of torsade de pointes (Figure 2) and degenerated into ventricular fibrillation and needs several DC shock. Temporary pacemaker was inserted on the rate of 100 beats/min and no ventricular premature contraction was seen. Metoprolol $25 \mathrm{mgs}$ b.i.d., furosemide $40 \mathrm{mg}$ od, perindopril $2 \mathrm{mgs}$ od and increased to $4 \mathrm{mgs}$ od was given. On the day 5 , while the patient on beta-blocker (metoprolol $100 \mathrm{mgs}$ b.i.d), bigeminy ventricular premature contraction was still documented and the pacemaker rate was increased up to 110 beats/min. On the day 12, DDD pacemaker was successfully implanted and the patient was discharged on the day 15 . The pacemaker was programmed on the rate $100 \mathrm{bpm}$ and prolonged $\mathrm{AV}$ delay $(250 \mathrm{~ms})$ to make more chance at their own ventricular beat (Figure 3). During follow-up at the out-patient's clinic, she was doing well and no syncopal episode occurred.

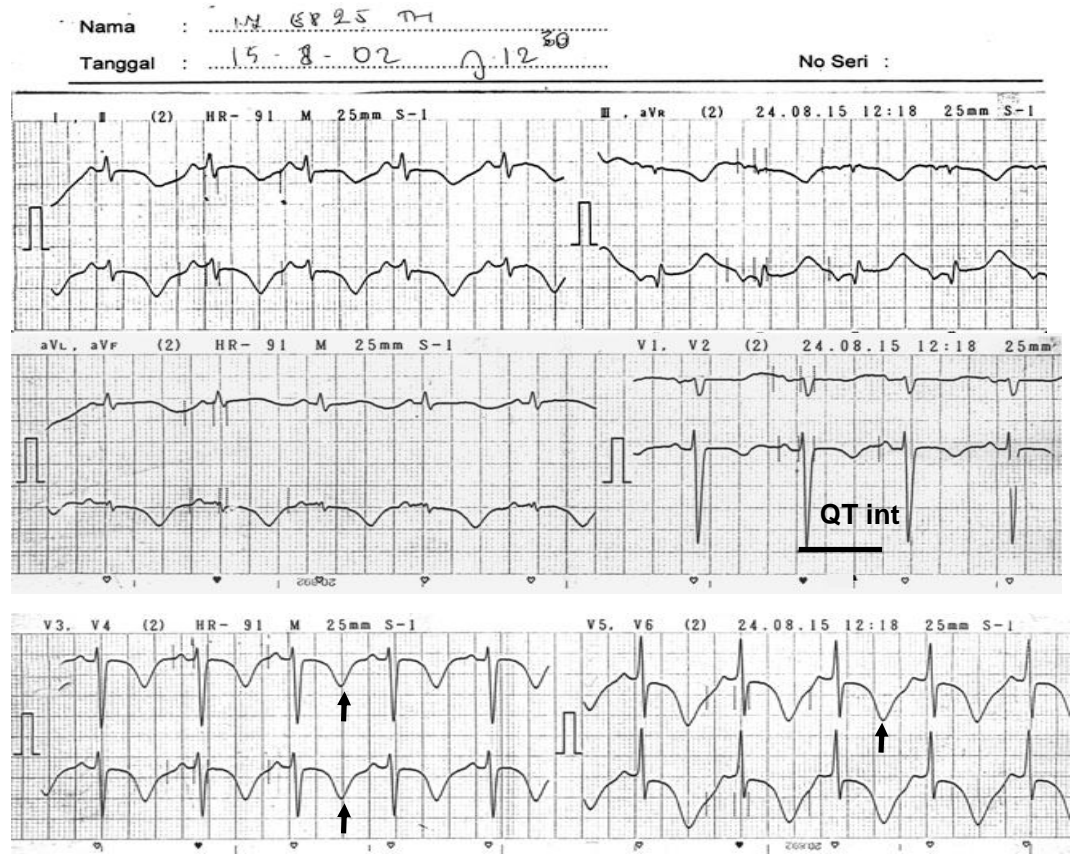

Figure 1. On admission, electrocardiogram showed sinus rhythm with long corrected QT interval (660 ms).There was a wide displayed and inverted $T$ wave (black arrows)

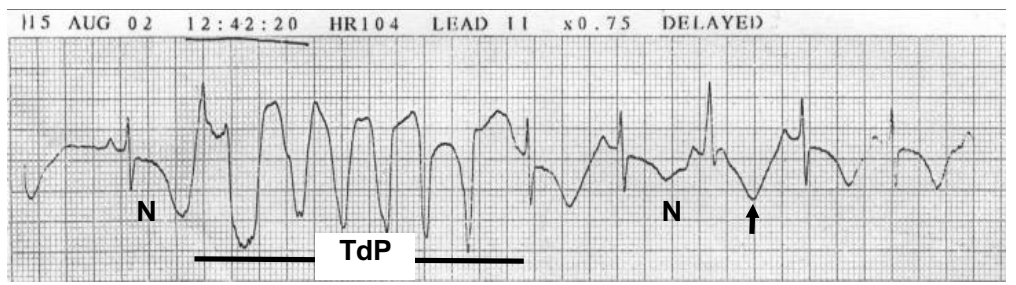

Figure 2. There were a short Torsade de pointes and T wave alternans (arrows) 


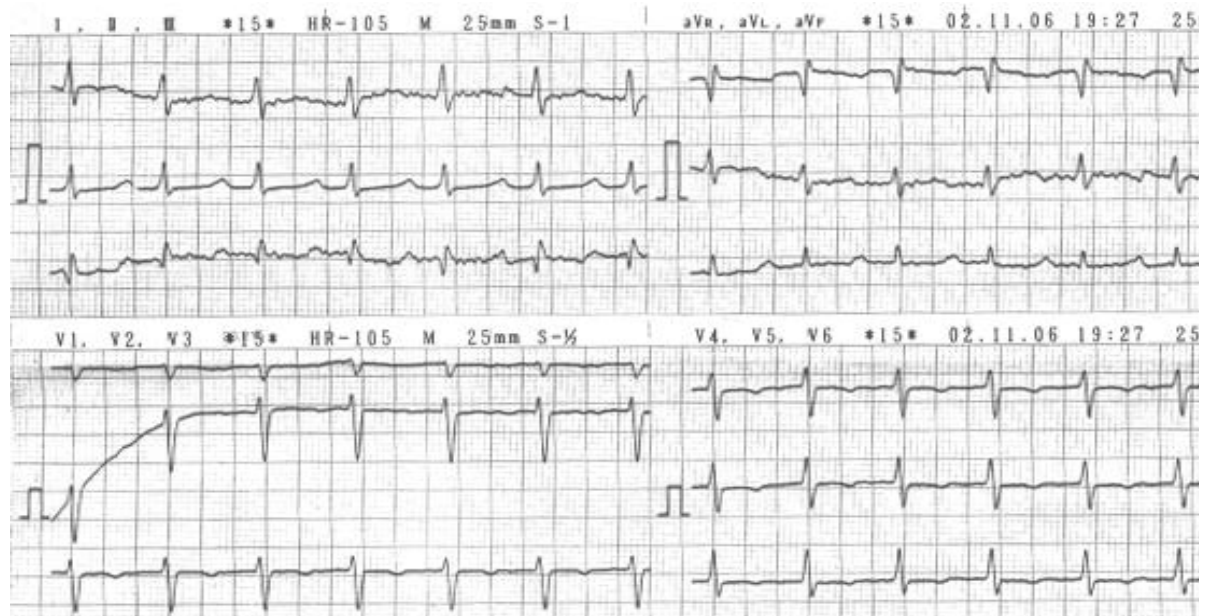

Figure 3. ECG tracing after 4 months of permanent pacemaker. The QTc interval is 0.44 . There is no more PVC nor alternans $T$ wave and she is doing well. The pacemaker was programmed at the rate of $100 \mathrm{bpm}$ and the AV delay of $250 \mathrm{~ms}{ }^{1}$

\section{DISCUSSION}

The prolongation of corrected QT interval is best seen in lead II, V1, V3 or V5 but all 12 leads should be examined and avoid $\mathrm{U}$ wave in QT measurement. Schwartz et al. developed a scoring system to enhance diagnosis reliability, and the scoring system are: 1 point as low probability; 2 to 3 points as intermediate probability; and $>4$ points as high probability (Table 1). ${ }^{4,5}$ In our case, the diagnosis of LQTS was clear, based on prolongation of corrected QT interval (3 point); documented torsade de pointes (2 point ); markedly $\mathrm{T}$ wave alternans (1 point) and history of syncope on exercise (2 point) .

Table 1. Diagnostic criteria for Long QT syndrome ${ }^{3}$

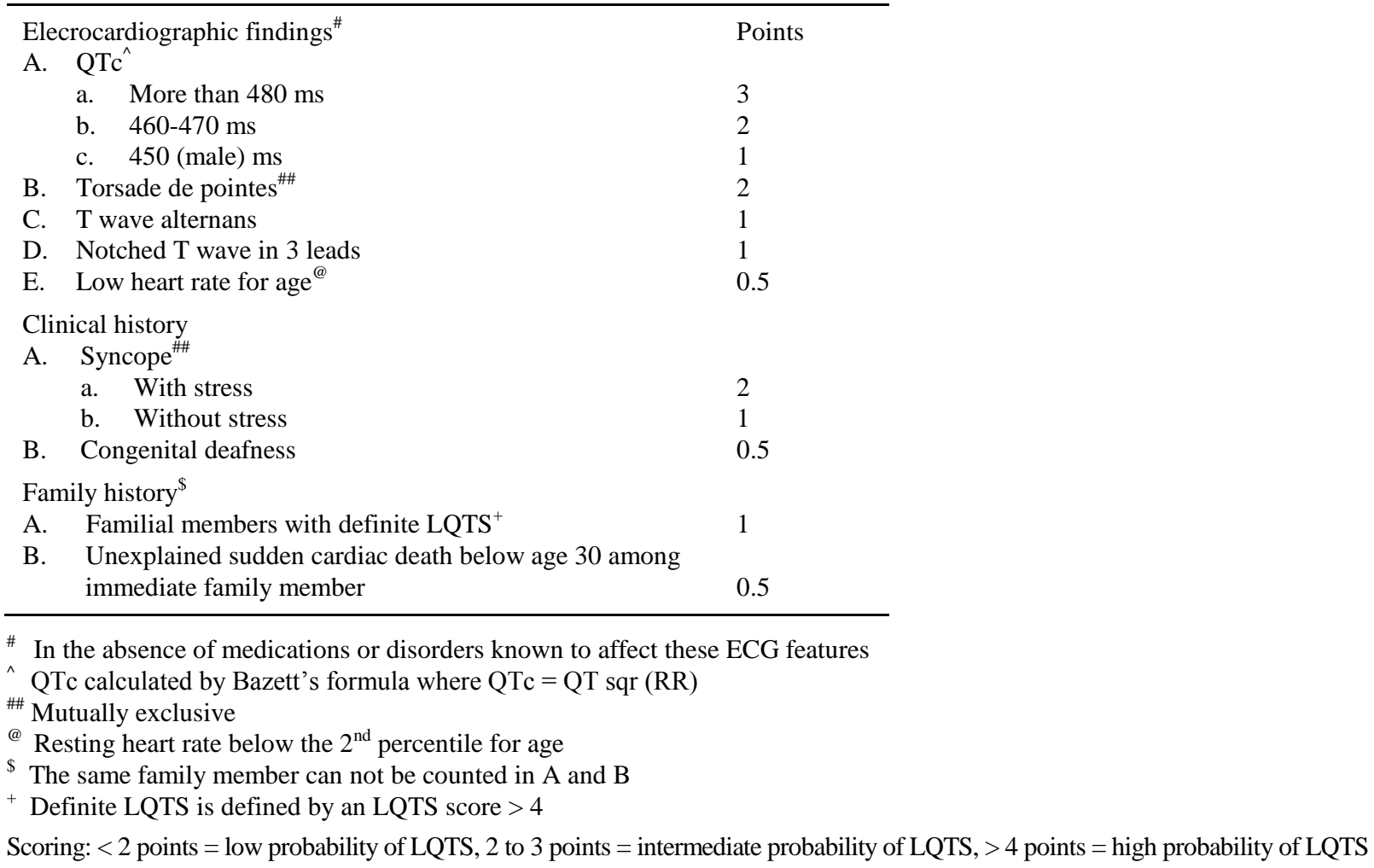


The total points is 8 . There are two groups of etiology in LQTS. The first is caused by genetic defect. At present, 6 mutant genes encoding protein of the cardiac ion channels have been identified as responsible for LQTS. All of these 6 genetic defects are associates with abnormalities in potassium and sodium channels and each defect has different clinical features. ${ }^{4}$ The second group consists of many etiology such elderly, drugs, electrolyte disturbance, metabolic disturbance, myocardial ischemia, and cardiomyopathy. The echocardiography of our case concludes that she suffered from peripartal cardiomyopathy soon after the first baby was born. Fortunately, on admission she brought her first ECG when she was 16 years of age which showed prolonged QTc interval $(560 \mathrm{~ms})$ and a broad base $\mathrm{T}$ wave with bigeminy ventricular premature contraction. This ECG proved that LQTS has already detected before her pregnancy. We didn't perform any genetic study in this case, but based on the medical history and 12 leads ECG we suggest, an autosomal dominant inheritance with defect on chromose locus 11p15.5, namely KVLQT1 might be responsible as the bell wether of her syndrome. Malignant arrhythmias in these subgroups of LQTS are easily triggered by exercise or emotional stress which occurred several times in her life. This gene has protein subunits to form the channel responsible for $\mathrm{I}_{k s}$. In LQTS1, normal and mutant KVLQT1 alleles are co expressed in myocites and in either case $\mathrm{I}_{k s}$ is decreased, resulting in prolongation of cardiac repolarization and increased risk of arrhytmias. ${ }^{3}$ We have to say that she was lucky, since she was being 'neglected' for almost nine years and not a single sustained malignant arrhythmia occurred since the first documented prolonged QTc interval. In order to prevent any cardiac events, there is a treatment steps for LQTS. For the time being, beta blocker (except sotalol) is the first line drug and supposed to be adjusted to maximal dose. The next steps are cardiac pacing, left cardiac sympathetic denervation, implantable cardioverter defibrillator (ICD) and gene therapy ${ }^{3,6}$. Although some defects are less sensitive to beta blockers, this agent has become the drug of choice for LQTS, regardless the site of genetic defect. There is no doubt in using beta blockers since in Romano Ward syndrome, the triggers for many life threatening arrhythmias are emotional and physical stress (85\%). which may be associated with a sudden increase in sympathetic activity. But the precise mechanism of the efficacy of beta blockers in LQTS remains unclear. One possible mechanism for beta blockers efficacy is inhibition of reactivated inward $\mathrm{Ca}$ current and this mechanism may be applicable to all forms of LQTS. Moreover, beta blocker might be particularly effective in arrhythmias caused by increased circulating catecholamines. ${ }^{3,6,7}$ Our patient was symptom free after taking metoprolol 100mg b.i.d. On day 5, ECG monitor showed bigeminy VPC and we decide to implant a DDD pacemaker The beneficial effects of pacing in high risk LQTS relate to the prevention of bradycardia and pauses and the shortening the QT interval. However, it should be used as an adjunct to beta blocker. Permanent cardiac pacing reduces the rate of recurrent syncopal events on high risk LQTS patients, but still, it does not provide complete protection. $^{8,9}$

\section{CONCLUSION}

Early detection in QTc interval may be helpful to diagnose LQTS particularly in patient with recurrent syncope. Implanting a permanent pacemaker as an adjunct therapy to beta blocker may reduce the syncopal events and enhanced the quality of life as well.

\section{REFERENCES}

1. Moss AJ, Schwartz PJ, Crampton RS, Locati E and Carlenn E. The long QT syndrome: a prospective international study. Circulation 1985;71:17-21

2. Moss AJ, and Robinson $\mathrm{J}$ Clinical features of the idiopathic long QT syndrome. Circulation 1992;85(suppl I): $140-4$

3. Splawski I, Shen J, Timothy KW, Lehmann MH, Priori S, Robinson JL et al. Spectrum of mutations in long-QT syndrome genes. KVLQT1, HERG, SCN5A, KCNE1, and KCNE2. Circulation 2000;102:1178-85

4. Bednar MM, Harrigan EP, Anziano RJ, Camm AJ and Ruskin JN. The QT interval. Progress Cardiol 2001;43 (suppl I):1-45

5. Maron BJ, Moller JH, Seidman CE, Vincent GM, Dietz $\mathrm{HC}$, Moss AJ et al. Impact of laboratory molecular diagnosis on contemporary diagnostic criteria for genetically transmitted cardiovascular diseases: Hyperthrophic cardiomyopathy, Long QT syndrome and Marfan syndrome. Circulation 1998;98:1460-71

6. Schwart PJ, Locati EH, Moss AJ, Crampton RS, Trazzi R and Ruberti U. Left cardiac sympathetic denervation in the therapy of congenital long QT syndrome; a worldwide report. Circulation 1991;84:503-11

7. Moss AJ, Zareba W, Hall J, Schwartz PJ, Crampton RS, Benhorin J, Vincentt GM, et al. Effectiveness and 
limitations of beta-blocker therapy in congenital long QT syndrome. Circulation 2000;101:616-23

8. Campanelli B and Chaudron JM. Long term follow up of long QT syndrome treated by overdrive paving. Heart 2000;86:14
9. Moss AJ, Liu JE, Gottlieb S, Locati EH, Schwartz PJ and Robinson JL. Efficacy of permanent pacing in the management of high risk with long QT syndrome. Circulation 1999;200:2431 
